\title{
Старе и ретке књиге легата академика Драгутина Анастасијевића
}

\author{
Маја Аћимовић \\ macimovic@bfspc.bg.ac.rs \\ Зоран Ранковић \\ zrankovic@bfspc.bg.ac.rs \\ Универзитет у Београду, \\ Православни богословски факултет, Београд
}

\begin{abstract}
Сажетак
У раду су представљени резултати истраживања о легату академика Драгутина Анастасијевића који је похрањен у библиотеци Православног богословског факултета Универзитета у Београду. После кратког животописа легатора, издвојене су мање познате чињенице о највећем, али и једном од најзначајнијих легата Православног богословског факултета, који у свом фонду садржи грађу изузетног научног потенцијала, са великим бројем публикација важних за изучавање и развој византолошких студија и историје српског народа. Поред тога, дат је и приказ одређеног броја наслова који, по Критеријумима за процену и категоризацију старе и ретке библиотечке грађе Закона о старој и реткој библиотечкој грађи, спадају у старе и ретке књиге. По богатству њиховог садржаја и вредности, поред тога што чине значајну културну баштину, представљају изузетно ретку и вредну научну грађу, како код нас, тако и у свету.
\end{abstract}

Кључне речи: Драгутин Анастасијевић (1877-1950), византолог, легат, Православни богословски факултет, културно наслеђе, стара и ретка књига

\section{Увод}

Личне библиотеке из оставштине значајних личности из света науке, културе, уметности, често су биле темељи на којима су се градиле библиотеке у Србији. Оне су свакако значајне за проучавање историје и културе једног народа, али и за проучавање индивидуалног стваралаштва самих легатора.

Према речима В. Прелића, легати људи који су се својим радом истакли у културном, уметничком или научном животу заједнице су један од облика друштвеног памћења. Културне институције их чувају јер представљају основне културне и цивилизацијске вредности једног друштва. Такође истиче да сваки легат има јасну симболичку и „употребна вредност". ${ }^{1}$

Посматрајући легате на овај начин, може се рећи да лична библиотека академика Драгутина Анастасијевића, која је у виду легата похрањена у библиотеци Православног богословског факултета Универзитета у Београду, свакако има симболичку, али и „употребну вредност”, значајну за стварање нових научних радова заснованих на материјалу који се у њему налази. Легат поседује публикације које су вредан део националне и светске културне баштине, која је уједно и научна грађа од изузетног значаја, пре свега за проучаваоце византологије и историје српског народа. Захваљујући академику Анастасијевићу, Православни богословски факултет данас поседује вредна ретка издања публикација из 19. века, издања из ратних година, стару периодику, вредну секундарну литературу. Ова драгоцена библиотека чува се као целина због

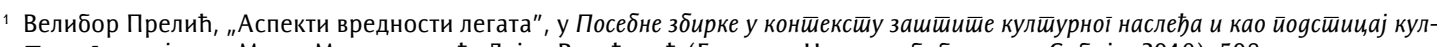
йурноі развоја, ур. Маша Милорадовић, Дејан Вукићевић (Београд: Народна библиотека Србије, 2019$), 508$. 
своје културне, научне и историјске вредности, али и због значаја и угледа проф. Драгутина Анастасијевића, који је својим преданим радом и истраживањима изузетно допринео проучавању српске историје, као и развоју науке код Срба.

Овај рад настоји да истакне вредност Анастасијевићевог легата, да га представи јавности те да омогући истраживачима да искористе сва сазнања и податке ретке научне грађе.

\section{Поклон-библиотека Драгутина Анастасијевића на Православном богословском факултету}

Библиотека Драгутина Анастасијевића инвентарисана је 1969. године у посебној инвентар-

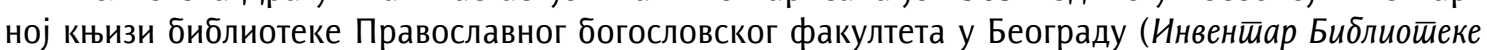

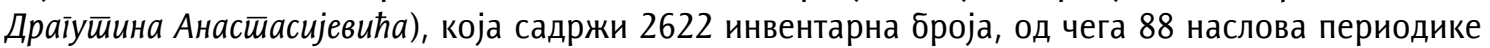
на разним језицима. Поклоњене књиге сведоче о стваралачкој личности некадашњег власника, али представљају и данас вредне изворе за изучавање византологије као историјске научне гране.

Драгутин Анастасијевић рођен је 1877. године у Крагујевцу, ${ }^{2}$ где је завршио основну школу и гимназију. Велику школу у Београду завршио је 1900. године испитом из класичне филологије. Почетком 1902. године послат је на студије византијске филологије у Минхен, код познатог професора Карла Крумбахера. Школовање у Минхену завршио је усменим докторским испитом из византијске и новогрчке филологије као главне струке и из класичне и романске филологије као помоћних струка. Своју докторску дисертацију „Die paränetischen Alphabete in der griechischen Literatur"3 штампао је неколико година касније у Минхену. Дисертација се бави моралним грчким буквицама, тј. врстом песама са азбучним акростихом моралне садржине.

Универзитетску каријеру почео је постављењем 20. маја 1906. године за привременог, а 20. фебруара 1908. за сталног доцента византологије на Филозофском факултету Универзитета у Београду. Предавао је „три огромне области из науке о Византији: језик (средњовековни грчки књижевни језик и новогрчки народни говор), историју византиске књижевности и историју Византије". ${ }^{4}$ Основао је библиотеку Семинара за византологију, којој је прибројао и своје личне књиге. ${ }^{5}$ Библиотека је тешко страдала током Првог светског рата, након кога је Анастасијевић морао да улаже велике напоре да семинарску библиотеку васпостави и даље развије. ${ }^{6}$ у обнову библиотеке уложио је много љубави, труда и енергије и он је најзаслужнији за то што Филозофски факултет располаже „прилично богатом и одлично пробраном стручном византолошком библиотеком". 7

После отварања Православног богословског факултета на Универзитету у Београду, Савет Факултета на седници одржаној 30. новембра 1920. године бира Драгутина Анастасијевића за редовног професора за грчки језик и историју византијске културе. ${ }^{8}$ Указом Њ. В. Краља од 1. јануара 1921. године (П. Бр. 150), бива и постављен за редовног професора на Православном богословском факултету. ${ }^{9}$ На Филозофском факултету остао је, као хонорарни професор, у својству управника Семинара за византологију све до 1931. године ${ }^{10}$ и предавао је историју Византије.

\footnotetext{
2 Негослав Јованчевић, „Професор Богословског факултета у Београду Драгутин Анастасијевић из Крагујевца и ометање рада овог факултета после Другог светског рата", у Сеgамgесей іоgина оg оснивања Шумаgијске ейархије, ур. Негослав Јованчевић (Крагујевац: Каленић, 2018), 103-129.

3 "Параенетички алфабет у грчкој литератури".

${ }^{4}$ Архив Православног богословског факултета (АПБФ), Професорски досије Драгутина Анастасијевића, „Аутореферат”, 8.

5 Исто, 10.

6 Љубомир Максимовић, „Развој византологије”, у Универзишеше у Беоїраgу 1838-1938 (Београд: Универзитет [итд.], 1988), 659.

7 Сйо їояина Филозофскої факулиетеша (Београд: Народна књига, 1963), 249

8 АПБФ, Записник, књ. I (1920-1930), „Записник седнице факултетског савета одржане 30. новембра 1920. године”, 8.

9 АПБФ, Професорски досије Драгутина Анастасијевића, „Службенички лист”, 4

10 Максимовић, „Развој византологије”, 659.
} 
Као млад универзитетски наставник, Анастасијевић је много путовао. Истраживао је у библиотекама Беча, Берлина, Лајпцига, Дрездена, Италије, Грчке, Русије и у Руском археолошком институту у Цариграду. ${ }^{11}$ Као професор Православног богословског факултета путовао је на Свету Гору ради научног истраживања, а такође и по старој Рашкој, сакупљајући материјал за српску историју. Систематично и методолошки је прикупљао вредну литературу кад год и где год је био у прилици и тако богатио своју библиотеку.

Са Јованом Радоњићем, Николом Вулићем и Филаретом Гранићем организовао је Други међународни конгрес византолога, који је одржан у Београду 1927. године. Већ тада је био у изузетним односима са својим колегама, светским именима из области византологије, учесницима Конгреса од којих су данас у легату сачуване поклоњене књиге са посветама које то и доказују.

За време окупације у Другом светском рату, професор Анастасијевић је пензионисан и 7. септембра 1942. године разрешен дужности. Као почасни професор задржан је на Православном богословском факултету, ${ }^{12}$ на коме је остао све до свога упокојења, 20. августа 1950. године. ${ }^{13}$

Своју богату личну библиотеку, са извесним ретким делима, завештао је и предао Православном богословском факултету. ${ }^{14}$

У првим годинама након Другог светског рата, ради даљег напретка византолошких студија у Београду, приступило се, између осталог, проширивању. Имајући у виду научну вредност библиотеке академика Драгутина Анастасијевића, Српска академија наука, у оквиру које је 1948. године основан Византолошки институт, ${ }^{15}$ обраћа се Православном богословском факултету са молбом да Анастасијевићеву библиотеку, не оспоравајући да је она власништво Православног богословског факултета, чува у Институту. Наставнички савет Факултета, проучивши ову молбу, и, с обзиром на потребе и интересе Факултета, сагласно је донео одлуку да не изађе у сусрет жељи председника Српске академије наука. ${ }^{16}$

Тако је лична библиотека професора Драгутина Анастасијевића остала у просторијама Православног богословског факултета до дана данашњег као легат.

Да би се поштовала жеља дародавца, библиотека је сачувана као целина и заведена је у фонду библиотеке Православног богословског факултета као посебна библиотека са ознаком ДА. Последњим пописом легата, 2010. године, утврђено је да недостаје одређени број библиотечких јединица.

У легату академика Драгутина Анастасијевића највећи број књига се односи на византијску и средњовековну историју српскога народа, област којој се највише посветио и коју је највише истраживао. На једном месту се налазе дела чувеног професора Лондонског универзитетског

11 Атанасије Јевтић, „Др Драгутин Анастасијевић”, Боїословље број 39 (1980): 9.

12 Професорски досије Драгутина Анастасијевића, 96.

13 У току рата, здравље Драгутина Анастасијевића је, услед слабе исхране, ослабило, нарочито вид, због чега је и његова радна способност осетно смањена те га је то спречило да заврши неке своје радове које је у међувремену започео.

14 "Давно сам већ обећао, да ћу своју библиотеку завештати нашем факултету. Она се састоји из осам стелажа, пуних стручним књигама и часописима, махом врло ретким и драгоценим, а смештена је у једној соби нашег факултета. Ја је још од сад поклањам факултету с тим да њоме слободно располаже, неограничен од мене у том погледу никаквим мојим жељама. Јер ми је толико ослабио вид, да једва могу што прочитати и написати, а камо ли студирати и радити даље на науци. Ако бих је, дакле, задржао у свом власништву до смрти, она би све дотле остала тако рећи мртва. Корисније је да је факултет још сад попише и уради с њом што за најбоље нађе. На захтев Факултетског савета прилажем овде једну своју фотографију." - АПБФ, Записник, књ. IV (1945-1948), „Записник бр. 14 седнице Савета богословског факултета одржане 2. фебруара 1948, чл. 101”.

15 Максимовић, „Развој византологије”, 668.

16 "Савет Православног богословског факултета је потпуно свестан значаја оснивања Византолошког института при Српској академији наука, и учиниће све да библиотека проф. нашег факултета Др Драгутина Анастасијевића буде приступачна за све научне раднике који се желе њоме користити, али жали, што не може изаћи у сусрет жељи претседника Српске академије наука, да се иста изнесе из просторија Богословског факултета, јер хоће да све библиотеке факултета буду под факултетским надзором и сакупљене у факултетској згради. " - АПБФ, Записник, књ. IV (1945-1948), „Записник бр. 14 седнице Савета богословског факултета одржане 2. фебруара 1948, чл. 102". 
колеџа Нормана Хепбурна Бејнса (Norman H. Baynes, 1877-1961), затим Карла Крумбахера (Karl Krumbacher, 1856-1909), А. Хајзенберга (August Heisenberg, 1869-1930), Пола Кречмера (Paul Kretschmer, 1866-1956), Албина Леског (Albin Lesky, 1896-1981), Никоса Веиса (Nikolaos Athanasiou Veis, 1887-1958), Ф. Делгера (Franz Doelger, 1891-1968), Николаја Јорге (Nicolae lorga, 1871-1940) и многих других значајних византолога тога доба. Ту су и наслови из светске историје, филологије, црквене уметности, црквеног права, патрологије. Његова ерудиција се огледа кроз разноликост наслова који се могу наћи у легату. Поред богате приручне литературе (речници, лексикони, каталози, библиографије), у библиотеци се могу запазити и књиге: Фиїарова жениgба у преводу Милана Грола (Критички осврт Саве Јакића на

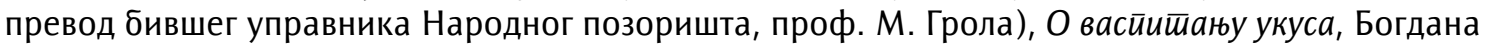
Поповића, Report of the Librarian of Congress and Report of the Superintendent of the Library Building and Grounds, 1907.

Једна од специфичности легата су и језици на којима су публикације објављиване. С обзиром на то да се усавршавао у иностранству, преовладава литература на страним језицима (немачком, француском, енглеском, грчком, руском, румунском, бугарском), а има је и на готици, црквенословенском и латинском.

Као академик и редовни професор Београдског универзитета, уживао је велики углед како у нашим, тако и у иностраним научним круговима. Из тог разлога је занимљиво, можда и неочекивано, да у легату нема велики број књига са посветама. Како му је то друга лична библиотека коју је, стицајем околности, поново формирао, јер је претходна била уништена, ${ }^{17}$ можемо претпоставити да је сам куповао и набављао наслове неопходне за даљи научни рад.

Требало би истаћи да је Факултет у процесу подношења предлога за проглашење легата културним добром, и то као целине. Дефинисање легата за културно добро довело би до стварања услова за његову потпуну правну и техничку заштиту, самим тим и за даље проучавање и објављивање резултата. Уз подршку Византолошког института Српске академије наука и уметности, намера нам је да се комплетан легат дигитализује.

\section{Старе и ретке књиге}

У легату Драгутина Анастасијевића постоји преко 400 наслова из 19. века, а по „Критеријумима за процену и категоризацију старе и ретке библиотечке грађе"18 има 38 старих и ретких књига (од тога 10 припадају старој и реткој књизи, док су осталих 28 из ратних периода и убрајају се у ретка издања). Оне чине посебан део легата, фонд старе и ретке књиге, који се убраја у покретна културна добра од великог значаја, али нису издвојене из првобитно замишљеног низа самог легатора, како се не би нарушио смисао целине легата. Њихов каталошки опис урађен је методом de visu по међународним стандардима за опис монографских публикација $\operatorname{ISBD}(M)$.

Књиге су тренутно сложене на покретним полицама у депоу зграде Православног богословског факултета заједно са фондом осталих легата и библиотека целина. Систем смештаја књига у легату је решен на принципу numerus currens, онако како је и првобитно била пописана библиотека.

\footnotetext{
17 Целокупна библиотека Драгутина Анастасијевића је, заједно са научним папирима које је оставио у стану, тешко страдала током гранатирања Београда у Првом светском рату. Након тога је морао да улаже велике напоре да формира и даље развије нову личну библиотеку. - Ђорђе Бубало, "Драгутин Анастасијевић на Светој Гори 1906/7. и 1912. године”, Хиланgарски зборник broj 14 (2017): 290.

18 Према законском одређењу, стару и ретку књигу сачињавају рукописи, рукописне и штампане књиге, периодика и друга библиотечка грађа настала до краја 1867. године, ретке књиге, одређени примерци периодичних издања и друге ретке библиотечке грађе настале и после ове године, као и посебне библиотечке целине које су због свог садржаја, уметничке, културне и историјске вредности значајне за науку и културу. - „Закон о старој и реткој библиотечкој грађи”, Службени іласник РС бр. 52 (2011).
} 
Највећи број старих и ретких књига је активан, односно у свакодневном је оптицају и на услузи корисницима, уз услов да се могу користити искључиво у просторијама читаонице библиотеке, уз надзор и помоћ библиотекара. Тај део књижевне баштине је мало познат широј читалачкој публици. Својим садржајем превазилази локална и регионална интересовања и сазнања, тако да је од изузетне вредности за шира научна истраживања и потражња за њим је запажена. Из тог разлога, ове године, када обележавамо 100 година Православног богословског факултета, а уједно и 70 година од смрти његовог највећег легатора, биће организована изложба легата Драгутина Анастасијевића, где ће се посебно представити сви примерци старе и ретке књиге. Ова изложба личне библиотеке Драгутина Анастасијевића омогућиће боље упознавање са самим легатором, његовим начином размишљања, методом рада, областима интересовања и научног истраживања. Напомене, коментари, означавање појединих важних делова на маргинама многих књига сведоче о његовим мислима и уверењима, а поједини коментари су студије-минијатуре о одређеним питањима и темама којима је књига посвећена. Примера ради, књига под сигнатуром ДА-93, The Genesis der byzantinischen Themenverfassung, има руком писани резиме на папиру: Стање Византијске

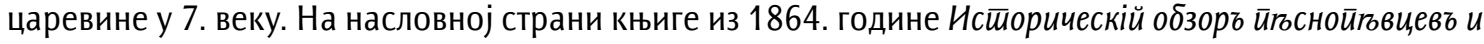
йъснойънія іреческой иеркви, сазнаје се како је разрешио иницијале аутора Ф.А.Ч. дописавши графитном оловком Филарет архиеп. Черњиговски (пример под сигнатуром ДА-1133).

Од свих старих и ретких књига из легата Драгутина Анастасијевића, дванаест наслова је већ дигитализовано, како у нашим, тако и у највећим светским библиотекама. ${ }^{19}$ Од тога је осам старих и ретких књига, а четири ретке ${ }^{20}$ књиге. То неће умањити значај дигитализације конкретних примерака који су припадали академику Анастасијевићу, јер ће на тај начин бити омогућен приступ свим специфичностима (потписи, записи, илустрације, коментари итд.) који би били значајни истраживачима из разних области науке (византологије, књижевности, али и онима који истражују старе књиге, историју библиотека, читања и слично)

Како се у легату, међу старим и ретким књигама, налазе штампане књиге на страним језицима, свакако би требало истаћи да стару српску књигу чине и рукописне и штампане књиге на страним језицима, ако им је аутор припадник српског народа. Тако да су пажње вредни на-

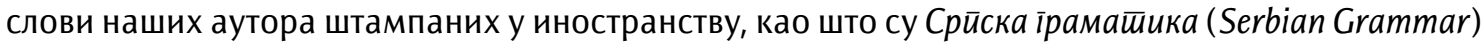
Драгутина Суботића, штампана у Оксфорду 1918. године, затим књига Јанка Спасојевића, Le roi Nicolas et l'union du Montenegro avec la Serbie, штампана у Женеви 1918. године, као и Г. Јакчића, La Bulgarie et les Allies, штампана 1916. године у Паризу.

Најстарија књига у легату је из 1810. године: Kritischer versuch zur aufklaerung der byzantischen chronologie: mit besonderer Rücksicht auf die frühere Geschichte Russlands, Филипа Круга (Philipp Krug). Овај редак примерак у свету дигитализован је у Руској државној библиотеци (Российская государственная библиотека) и може се наћи на интернету. ${ }^{21}$

Неки од познатијих наслова старих књига из 19. века које је професор Драгутин Анастасијевић користио у свом научном раду, значајних за проучавање историје Византије су: Cantacuzène, homme d'etat et historien: ou Examen critique comparatif des Mémoires de l'empereur Jean Cantacuzène et des sources contemporaines, et notamment des 30 livres dont 14 inédits de l'Histoire byzantine de Nicéph. Grégoras, qui contrôlent les Mémoires de Cantacuzène из 1845. године, затим чувено дело Феликса Каница о српским византијским споменицима, Serbiens byzantinische Monumente, из 1862. године.

${ }^{19}$ Библиотеке попут: Harvard College Library, The Digital Library of Modern Greek Studies, Руска државна библиотека и друге.

20 „У ретке књиге убрајају се рукописне књиге настале после 1867. године, ретка издања из ратних периода 1912-1913, 19141918, 1941-1945, издања са тиражом мањим од 100 примерака ако имају посебну научну, историјску, културну или уметничку вредност, примерци публикација који због посебне опреме или садржине излазе из профила укупног тиража, цензурисана, емигрантска издања објављена ван Србије." - Марина Митрић, „Легати и библиотеке целине у јавним библиотекама Србије - прилог за регистар старе и ретке библиотечке грађе", у Леїашии и библиошеке иелине, ур. Татјана Брзуловић Станисављевић (Београд: Заједница матичних библиотека Србије; Крагујевац: Народна библиотека „Вук Караџић, 2016$), 56$.

21 Philipp Krug, Kritischer versuch zur aufklaerung der byzantischen chronologie : mit besonderer Rücksicht auf die frühere Geschichte Russlands (St. Petersburg: Kais. Akademie der Wissenschaften, 1810), preuzeto 26. 3. 2020, https://dlib.rsl.ru/viewer/01004443090 
Значајан је и примерак публикације из 1828. године, Leonis Diaconi Caloënsis Historiae libri decem et liber De velitatione bellica Nicephori Augusti / e recensione Caroli Benedicti Hasii... addita eiusdem versione atque annotationibus ab ipso recognitis; accedunt Theodosii acroases de Creta capta e recensione Fr. Iacobsii et Luitprandi legatio cum aliis libellis qui Nicephori Phocae et Ioannis Tzimiscis historiam illustrant, која се још само може наћи у Библиотеци Матице српске као део личне библиотеке Саве Текелије. Ова књига писана на латинском и старогрчком била је неизоставна литература из дела историје коју је професор Драгутин Анастасијевић посебно изучавао. ${ }^{22}$

Занимљиво је и дело Арчибалда Рајса које спада у ретка издања из ратних периода, Ау-

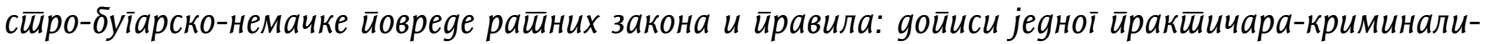
сие са срйскої маћеgонскої фронйа, из 1918. године.

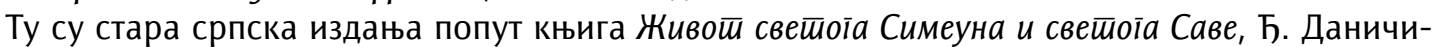

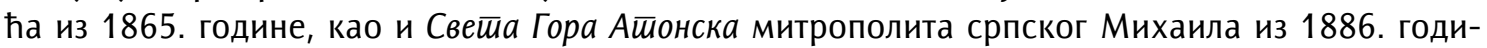
не, затим књига Јована Колара, О кньижевной узаймносиии између различни йлемена и нарегиія славянскоїв нароga, из 1845. године, у преводу Димитрија Теодоровића на српски књижевни језик средине 19. века, са елементима славеносрпског.

Неки примерци су штампани као сепарати, што никако не умањује њихов значај.

Требало би истаћи да књижна грађа која се налази у легату, јединствени или веома ретки примерци, или целе збирке стручне литературе, пажљиво бирани наслови, фигуративно речено, чине портрет легатора. Имајући у виду досадашње потребе и антиципирајући будуће потребе корисника старе грађе, дигитализацијом би се, у првом реду, унапредио научноистраживачки рад. Исто тако, процесом дигитализације би требало да се на креативан и нов начин представе збирке старе и ретке књиге, са свим својим специфичностима сваког примерка и ширем кругу корисника.

\section{Закључак}

Иако старе књиге у легату Драгутина Анастасијевића, као и ретка издања из ратних периода, по аутоматизму имају статус културног добра, потребно их је, у складу са Законом, прогласити за културно добро, односно за културно добро од великог значаја. ${ }^{23}$ Факултет је у процесу подношења предлога за проглашење легата културним добром и то као целине. Дефинисање легата за културно добро довело би до стварања услова за његову потпуну правну и техничку заштиту, самим тим и за даље проучавање и објављивање резултата. Дигитализацијом грађе омогућила би се коначна, пре свега, заштита, али и доступност културног добра у виду старе и ретке књиге.

Потенцијал овог истраживања сагледава се, дакле, кроз истицање вредности садржаја легата, са посебним освртом на старе и ретке књиге, његовог представљања, које би омогућило истраживачима да искористе сва сазнања и податке ретке научне грађе. Такође, омогућава боље упознавање са самим легатором, професором Драгутином Анастасијевићем, његовим начином размишљања, методом рада, областима интересовања и научног истраживања кроз напомене, коментаре, означавање појединих важних делова на маргинама књига.

Данашње интересовање за ову библиотеку јасно указује да њен садржај пружа широке могућности истраживачима и то не само византолозима, већ и историчарима културе и књижевности, теолозима, етнолозима и другима.

\footnotetext{
22 О Нићифору Фоки и Јовану Цимискију Драгутин Анастасијевић је писао радове у реномираним светским научним часописима као што је Byzantinische Zeitschrift. Тој теми је посветио рад који је изложио на Трећем византолошком конгресу одржаном у Атини 1932. године. - Љубомир Никић, „Библиографија радова Академика Драгутина Н. Анастасијевића”, у 3борник раgова

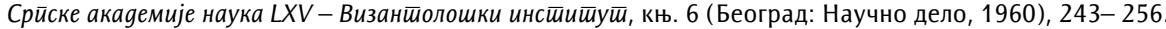

23 „Закон о старој и реткој библиотечкој грађи”.
} 


\title{
Литература и извори:
}

1. Arhiv Pravoslavnog bogoslovskog fakulteta (APBF). Profesorski dosije Dragutina Anastasijevića.

2. Arhiv Pravoslavnog bogoslovskog fakulteta (APBF). Zapisnik, knj. I (1920-1930).

3. Bubalo, Đorđe. „Dragutin Anastasijević na Svetoj Gori 1906/7. i 1912. godine”. Hilandarski zbornik (2017): 233-307.

4. Jevtić, Atanasije. „Dr Dragutin Anastasijević”. Bogoslovlje broj 39 (1980): 8-12.

5. Jovančević, Negoslav. „Profesor Bogoslovskog fakulteta u Beogradu Dragutin Anastasijević iz Kragujevca i ometanje rada ovog fakulteta posle Drugog svetskog rata". U Sedamdeset godina od osnivanja Šumadijske eparhije, urednik Negoslav Jovančević, 103-129. Kragujevac: Kalenić, 2018.

6. Krug, Philipp. Kritischer versuch zur aufklaerung der byzantischen chronologie: mit besonderer Rücksicht auf die frühere Geschichte Russlands. St. Petersburg: Kais. Akademie der Wissenschaften, 1810. Preuzeto 26. 3. 2020. https://dlib.rsl.ru/viewer/01004443090.

7. Maksimović, Ljubomir. "Razvoj vizantologije”. U Univerzitet u Beogradu 1838-1938, 655-671. Beograd: Univerzitet, 1988.

8. Mitrić, Marina. „Legati i biblioteke celine u javnim bibliotekama Srbije - prilog za registar stare i retke bibliotečke građe". U Legati i biblioteke celine, urednik Tatjana Brzulović Stanisavljević, 54-91. Beograd: Zajednica matičnih biblioteka Srbije; Kragujevac: Narodna biblioteka „Vuk Karadžić", 2016.

9. Nikić, Ljubomir. "Bibliografija radova Akademika Dragutina N. Anastasijevića”. U Zbornik radova Srpske akademije nauka LXV - Vizantološki institut, knj. 6, urednik Georgije Ostrogorski, 243-256. Beograd: Naučno delo, 1960.

10. Prelić, Velibor „Aspekti vrednosti legata". U Posebne zbirke u kontekstu zaštite kulturnog nasleđa i kao podsticaj kulturnog razvoja, urednici Maša Miloradović, Dejan Vukićević, 507-511. Beograd: Narodna biblioteka Srbije, 2019.

11. Sto godina Filozofskog fakulteta. Beograd: Narodna knjiga, 1963.

12. „Zakon o staroj i retkoj bibliotečkoj građi”. Službeni glasnik RS br. 52 (2011).

\section{Old and Rare Books in the Legacy Collection of Academician Dragutin Anastasijević}

\begin{abstract}
Summary
This paper presents the results of the research on the legacy collection of academician Dragutin Anastasijević, which is stored in the library of the Faculty of Orthodox Theology of the University of Belgrade. After a short biography of the legator, the paper highlights the less known facts about the largest, but also one of the most important legacy collections of the Faculty of Orthodox Theology, which contains material of outstanding scientific potential with a large number of publications important for the development of Byzantine studies and the study of Serbian history. In addition, a number of titles were presented which, according to the Criteria for the Evaluation and Categorization of Old and Rare Library Materials of the Law on Old and Rare Library Materials, belong to the category of old and rare books. They are not only a significant cultural heritage, but an extremely rare and valuable scientific material, both within our country and in the world.
\end{abstract}

Keywords: Dragutin Anastasijević (1877-1950), byzantologist, legacy collection, Faculty of Orthodox Theology, cultural heritage, old and rare books 


\section{(ब) $(\Theta \Theta$}

Старе и ретке књиге легата академика Драгутина Анастасијевића by Маја Аћимовић, Зоран Ранковић is licensed under a Creative Commons Attribution-NonCommercial-NoDerivatives 4.0 International License. 